\title{
Reconstructing readiness: Young children's priorities for their early school adjustment
}

\author{
Early Childhood Research Quarterly: Authors' accepted version \\ Christine O'Farrelly ${ }^{\mathrm{a}}$, Ailbhe Booth ${ }^{\mathrm{b}, \mathrm{c}}$, Mimi Tatlow-Golden ${ }^{\mathrm{d}}$, Beth Barker ${ }^{\mathrm{a}}$
}

\begin{abstract}
${ }^{a}$ Centre for Psychiatry, Imperial College London, London, United Kingdom.
${ }^{\mathrm{b}}$ Geary Institute for Public Policy, University College Dublin, Dublin, Ireland.

${ }^{\mathrm{c}}$ School of Psychology, University College Dublin, Dublin, Ireland.

d Faculty of Wellbeing, Education and Language Studies, The Open University, Milton Keynes, United Kingdom.
\end{abstract}

c.ofarrelly@imperial.ac.uk (corresponding author)

Young children in communities facing socioeconomic disadvantage are increasingly targeted by school readiness interventions. Interventions are stronger if they address stakeholders' priorities, yet children's priorities for early school adjustment are rarely accounted for in intervention design including selection of outcome measures. The Children's Thoughts about School Study (CTSS) examined young children's accounts of their early school experiences, and their descriptions of what a new school starter would need to know. Mixed-method interviews were conducted with 42 kindergarten children in a socioeconomically deprived suburb of Dublin, Ireland. First, inductive thematic analysis identified 25 priorities across four domains: feeling able and enthusiastic for school; navigating friendships and victimisation; supportive environments with opportunities to play; bridging school and family life. Second, deductive analysis compared children's priorities at item level against a school readiness outcome battery. Children's priorities were assigned to three groups: (1) assessed by outcome measures (core academic competencies, aspects of self-regulation); (2) partially assessed (self-efficacy, social skills for friendship formation and avoiding victimisation, creative thinking, play); and (3) not assessed by outcome measures (school liking, school environment, family-school involvement). This analysis derived from children's own perspectives suggests that readiness interventions aiming to support early school adjustment would benefit from considering factors children consider salient. It offers recommendations for advancing conceptual frameworks, improving assessment, and identifying new targets for supporting children and schools. In doing so we provide a platform for children's priorities to be integrated into the policies and practices that shape their early lives.

Keywords: Children's perspectives, school readiness, school experience, socioeconomic disadvantage, early intervention, school adjustment

Acknowledgements We are grateful for support from the Children's Research Network who provided funding for the analysis of the Children's Thoughts about School Study data reported in this study. We also acknowledge support from Northside Partnership who provided funding for the Preparing for Life evaluation through the Department of Children and Youth Affairs and The Atlantic Philanthropies. We are grateful to all those who participated and supported this research, especially the participating children, families, and schools, the PFL intervention staff and the Expert Advisory Committee. We also extend sincere thanks to Dr Orla Doyle for her support of the CTSS, Early Childhood Research Team at the Geary Institute for Public Policy, Professor Eilis Hennessy who provided feedback on the CTSS protocol, as well as Claire O'Rourke, and Kathrin Kaulen for their contributions to the work and data collection. 
CHILDREN'S SCHOOL READINESS PRIORITIES O'Farrelly et al ECRQ 2019

\section{Socioeconomic Disadvantage and School Readiness}

An increasing number of young children are growing up in poverty, with a constellation of risk factors that can affect nearly all aspects of development (McLoyd, Aikens, \& Burton, 2006;

Schickedanz, Dreyer, \& Halfon, 2015). Inequalities tend to emerge early, remain stable or widen over time, and influence ongoing life chances (e.g., Duncan \& Magnuson, 2011). At school entry children from impoverished backgrounds are more likely to struggle with academic skills, behaviour problems, and self-regulation, and are less likely to be considered 'ready for school' than their advantaged peers (Isaacs, 2012; Shonkoff, 2015). In response to these early skills gaps that undermine complex skill development, interest is growing in early interventions that target school readiness and early school adjustment amongst children from disadvantaged backgrounds (Blair, 2002; Duncan et al., 2007; Heckman, 2007).

Interventions focusing on early influences (0-3 years), especially parent-child relationships, are believed to be particularly important (Center on the Developing Child, 2016; Doyle, Harmon, Heckman, \& Tremblay, 2009). One model, home visiting programmes (HVPs), seeks to promote school readiness by mitigating risks associated with poverty (Azzi-Lessing, 2011). Reviews show these interventions favourably affect child development and school readiness, yet effect sizes are small and there is little commonality in outcome measures (Filene, Kaminski, Valle, \& Cachat, 2013; Sama-Miller et al., 2016; Sweet \& Appelbaum, 2004).

\section{Conceptual and Operational Approaches to School Readiness}

The underlying premise of school readiness approaches is that children should be supported to adapt well to school and experience success there. Achieving this hinges on our ability to identify and support factors that contribute to such adaptation and success (Sabol \& Pianta, 2017). There is, however, no agreed definition of readiness, which has confused stakeholders and provoked debate (Britto, 2012; Kagan, 2007). Teachers tend to identify readiness as children's ability to communicate wants, needs and thoughts, having curiosity and enthusiasm for learning, and strong self-regulation and social skills, whereas parents typically prioritise literacy and numeracy skills (Rimm-Kaufman \& Sandilos, 2017).

Conceptually, idealist/nativist approaches view school readiness as a function of maturation, whereas empiricist/environmental perspectives attribute it to taught or learned skills, and social constructivist models link readiness to the social or cultural context (see Dockett \& Perry 2002; Meisels, 1999). A more helpful interactionist model (Meisels, 1999) sees readiness as reciprocally shaped by children's knowledge and skills, and schools' capacities to adapt to children, thus extending readiness to include families, schools, and communities (Dockett \& Perry, 2002). 
CHILDREN'S SCHOOL READINESS PRIORITIES O'Farrelly et al ECRQ 2019

Socioemotional and contextual features of school readiness are also reflected in Ladd (2009) and Ramey and Ramey (1994)'s characterisations of school adjustment. Early signals of readiness and success are demonstrated by children who like school; establish supportive social ties with teachers and classmates; feel comfortable and relatively happy in the classroom, rather than anxious, lonely or upset; are interested and motivated to learn and participate in activities; have caregivers who are engaged in their education; and are based in classrooms that are emotionally positive; amongst other criteria. Indeed, research shows that children's feelings towards school and early relationships foster ongoing participation and achievement (rather than the converse e.g., Ladd et al., 2000; Ladd \& Coleman, 1997; Valiente, Lemery-Chalfant, \& Castro, 2007). Thus, Ladd (2009) suggests that it is early socioemotional (e.g, school liking), rather than scholastic, factors that foster children's sense of belonging and attachment to school.

Most commonly, however, leading approaches operationalise school readiness without reference to a conceptual model and advocate taking a multi-dimensional multi-informant, multi-measure approach combining teacher and parent report, and child assessment to measure the cognitive, language, behavioural, motor, socioemotional and self-regulation abilities believed to support children's adjustment and functioning in school (Boivin \& Bierman, 2014; Sabol \& Pianta, 2017). The arising plethora of assessments has led to criticism that operational definitions of school readiness are as ambiguous as theory, and that a deficit focus risks overlooking important aspects of children's potential (Brown, 2018; Mashburn, 2014).

\section{Integrating Stakeholder Priorities in Assessment}

One means of interrogating the validity of outcome measures is to identify what is meaningful to service users themselves (e.g., Crawford et al., 2011; Singh, 2017). Yet, despite growing trends to incorporate stakeholder views into evaluations of complex interventions (Moore et al., 2015; see also Pawson \& Tilley, 1997), those targeting children's lives tend to privilege adults' observations over children's priorities and experiences. The value of gaining children's perspectives is acknowledged in policy and research (e.g., MacNaughton, Hughes, \& Smith, 2007) and asserted by the United Nations Convention on the Rights of the Child (1989). Yet efforts to understand young children's lived experiences are less common than those with older children (Lansdown, 2005; UN Committee on the Rights of the Child, 2005).

However, young children have the developmental capacity to make choices, express feelings and preferences, and demonstrate understanding of their environments (Lansdown, 2010). They have coherent and differentiated self-concepts and demonstrate understanding of their own emotional states, traits, and motives (e.g., Goodvin, Meyer, Thompson \& Hayes, 2008). Studies of the validity and reliability of young children's responding show that they can provide meaningful information in clinical, courtroom, education, and other settings, if appropriate tools and practices are employed 
CHILDREN'S SCHOOL READINESS PRIORITIES O'Farrelly et al ECRQ 2019

(Brown \& Lamb, 2015; Harrison, Clarke, \& Ungerer, 2007; Luby, Belden, Sullivan, \& Spitznagel, 2007). Therefore, consulting young children about their experiences is feasible.

\section{Children's Perspectives about their School Experiences}

Studies that have sought young children's perspectives on school have tended to focus on the early experiences and school adjustment of mixed and high SES communities. A collection of these studies from Australia and New Zealand find that children associate positive school experiences with good peer experiences and friendships, warm teacher relationships, being able to understand and meet rules and expectations, and enjoyment of learning; with negative experiences linked to peer rejection, separation anxiety, and conflicted teacher relationships (Dockett \& Perry, 2004; Margetts, 2006; Murray \& Harrison, 2005; Peters, 2003). Play is also important, and children from studies in the UK, Ireland and Iceland tend to lament its loss in school, seeing it as being valued less than 'work' (Brooker, 2008; Einarsdottir, 2010; Keating et al., 2000; O’Kane, 2007).

Although children from low SES backgrounds are often targets of considerable intervention efforts to promote school adjustment, few studies have elicited their perspectives. Available US studies show that children from disadvantaged backgrounds hold positive views of school, are optimistic about future schooling, hold similar opinions about their competence than their more advantaged peers (Entwisle \& Hayduk, 1978; Ramey et al., 1998; Seefeldt, Galper, \& Denton, 1997), but also report school as being less play-centred and more difficult than preschool (Seefeldt et al., 1997). In contrast, Skinner, Bryant, Coffman, and Campbell's (1998) ethnographic study of former Head Start children documented that some children hated school, were proud of aggressive behaviours, and found teachers' behavioural expectations unreasonable. Children in Hong Kong (Wong, 2015) also held concerns about teachers' expectations and children in Dockett et al.'s Australian study (2011) acknowledged their own behavioural difficulties. Similar to mixed SES samples, peers were framed as a source of support, play, and learning (Jackson \& Cartmel, 2013; Australia), but also of conflict and bullying (Wong, 2015). Although these studies are valuable, they are few, and their insight is constrained by structured measures and/or very small samples.

\section{Present Study}

In the context of conceptual and operational disarray, yet substantial financial investment in school readiness, it seems remiss that children's own experiences and priorities for their early adjustment to school remain poorly understood. No-one, to our knowledge, has interrogated the outcomes used to evaluate school readiness programmes against what is meaningful to children. As a key goal of school readiness interventions is to support children's adaptation to school, then children themselves are uniquely placed to provide insight into the difficulties they encounter as they adjust to school. The Children's Thoughts about School Study (CTSS) aimed to identify what is salient to children for their early adjustment to school and compare these priorities against school readiness outcome measures 
CHILDREN'S SCHOOL READINESS PRIORITIES O'Farrelly et al ECRQ 2019

employed in the Preparing for Life $(P F L)$ randomised controlled trial (RCT) of a school readiness intervention.

\section{Method}

\section{Research Context}

The CTSS formed part of a process evaluation within the RCT of $P F L$, a parenting intervention designed to promote children's school readiness (see Doyle, 2013 for description of the intervention and evaluation, ISRCTN04631728). The CTSS took place in the PFL target community, a socioeconomically disadvantaged community in Dublin, Ireland. Approximately $42 \%$ of the 15,384 inhabitants lived in social housing (national average: 7.2\%), 12\% were unemployed (national average: $3.5 \%$ ), and $7 \%$ had completed higher education (national average: 19.4\%) (Census, 2006).

\section{PFL Intervention}

The PFL RCT recruited 233 participants (January 2008 - August 2010) who were randomly allocated to either a high treatment $(n=115)$ or low treatment 'control' group $(n=118)$. As part of a manualised intervention (Preparing for Life \& The Northside Partnership, 2008), the high treatment comprised home visits targeting developmental milestones and appropriate parenting practices, baby massage classes, and the Triple P Positive Parenting Program (Sanders, Markie-Dadds \& Turner, 2003). Both groups received common supports including developmental materials and book packs, community-based workshops and events, and support in accessing community services.

\section{PFL Outcome Measures}

The PFL outcome evaluation assessed a primary outcome of school readiness across five domains: cognitive development, language development, approaches to learning, social and emotional development, and physical well-being and motor development. These domains correspond broadly with those outlined in the US National Education Goals Panel (1991), the US Head Start Early Learning Outcomes Framework, and the literature, and were selected after extensive literature review and expert consultation, reflecting state-of-the-art school readiness measurement.

Outcome measures were completed through maternal interviews, teacher-reported questionnaires including the short form of the Early Development Instrument (S-EDI; Janus, Duku, \& Stat, 2005), direct assessment of children's cognitive ability using the British Ability Scales II (BAS II; Elliott, Smith, \& McCulloch, 1996), and other measures. The S-EDI measures five school readiness domains; physical health and well-being, social competence, emotional maturity, language and cognitive development, and communication and general knowledge. Six of the BAS II subscales (verbal comprehension, naming vocabulary, picture similarities, early number concepts, pattern construction, and copying) were administered generating scores of children's verbal ability, pictorial reasoning, 
CHILDREN'S SCHOOL READINESS PRIORITIES O'Farrelly et al ECRQ 2019

spatial ability, and overall general conceptual ability. Further information is included in

Supplementary File A.

\section{CTSS Sampling, Recruitment, and Participants}

The CTSS purposefully sampled children from the PFL RCT high and low treatment groups, with a target of 15 per group, based on the phenomenological approach and interview method (Onwuegbuzie $\&$ Collins, 2007). A no intervention community ('comparison') group was also recruited to capture any further variation in children's perspectives. All children in their first school year (Junior Infants, equivalent to US Kindergarten/UK Reception classes) from one catchment school (7 classrooms; class sizes: 12-15 children) were approached in March 2014 and March 2015. The school was designated disadvantaged by the Irish Department of Education, receiving lower pupil to teacher ratios, school meals, books and other literacy and numeracy supports. Parents received a CTSS information pack with an illustrated child booklet. Half (54\%) of eligible families consented; $95 \%$ of children assented.

Table 1. Demographic Profile of High Treatment, Low Treatment, and Comparison Group

\begin{tabular}{|c|c|c|c|c|}
\hline & $\begin{array}{c}\mathrm{N} \\
\left(n_{\mathrm{HIGH}} /\right. \\
n_{\mathrm{LOW}} / \\
\left.n_{\mathrm{COMP}}\right)\end{array}$ & $\begin{array}{c}\text { High } \\
\text { treatment } \\
(\mathrm{n}=14)\end{array}$ & $\begin{array}{l}\text { Low treatment } \\
(n=13)\end{array}$ & $\begin{array}{c}\text { Comparison }^{1} \\
(n=15)\end{array}$ \\
\hline Mother age, M, SD & $\begin{array}{c}41 \\
(13 / 13 / 15)\end{array}$ & $32.3(5.30)$ & $30.0(6.19)$ & $30.3(5.09)$ \\
\hline Number living in household & $\begin{array}{c}40 \\
(13 / 12 / 15)\end{array}$ & $6.9(1.38)$ & $5.7(1.07)$ & $5.6(1.24)$ \\
\hline \multicolumn{5}{|l|}{ Level of education ${ }^{\mathrm{a}}, \mathrm{n}, \%$} \\
\hline $\begin{array}{l}\text { Left before completion of secondary } \\
\text { school }\end{array}$ & $\begin{array}{c}42 \\
(14 / 13 / 15)\end{array}$ & $10(71 \%)$ & $6(46 \%)$ & $10(67 \%)$ \\
\hline Completed secondary school final exam & $\begin{array}{c}42 \\
(14 / 13 / 15)\end{array}$ & $3(21 \%)$ & $5(38 \%)$ & $5(33 \%)$ \\
\hline Post-secondary education & $\begin{array}{c}42 \\
(14 / 13 / 15)\end{array}$ & $1(7 \%)$ & $2(15 \%)$ & $0(0 \%)$ \\
\hline Not in paid work, $n, \%$ & $\begin{array}{c}40 \\
(13 / 12 / 15)\end{array}$ & $8(62 \%)$ & $8(67 \%)$ & $11(73 \%)$ \\
\hline In receipt of social welfare payments & $\begin{array}{c}34 \\
(11 / 9 / 14)\end{array}$ & $11(100 \%)$ & $6(67 \%)$ & $12(86 \%)$ \\
\hline Single parent family, n, \% & $\begin{array}{c}40 \\
(12 / 13 / 15)\end{array}$ & $3(25 \%)$ & $5(38 \%)$ & $4(27 \%)$ \\
\hline Only child, $n, \%$ & $\begin{array}{c}42 \\
(14 / 13 / 15)\end{array}$ & $2(14 \%)$ & $3(23 \%)$ & $2(13 \%)$ \\
\hline Child Gender (boy), n, \% & $\begin{array}{c}42 \\
(14 / 13 / 15)\end{array}$ & $4(29 \%)$ & $5(38 \%)$ & $8(53 \%)$ \\
\hline
\end{tabular}

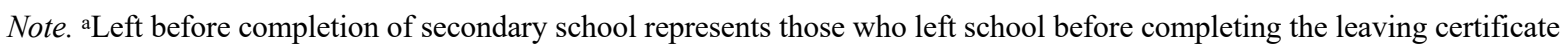
(final examination in secondary/high school, equivalent to UK GCE advanced level exam or receiving US high school diploma). Completed secondary school includes those who completed the leaving cert exam. Post-secondary education includes any education at a higher level than leaving cert (e.g. post leaving cert diploma/cert/degree).

CTSS participants were 42 children $(14=$ high treatment; 13 = low treatment; 15 = comparison group; 17 boys) aged on average 61.82 months $(S D=3.62$; range $=55.36-70.54)$; see Table 1 . Family characteristics reflected socioeconomic adversity in the catchment population: $62 \%$ parents had not completed secondary school, $68 \%$ were not in paid work, and $85 \%$ received social welfare payments. 
CHILDREN'S SCHOOL READINESS PRIORITIES O'Farrelly et al ECRQ 2019

Teachers, all female, had on average 8.57 years' teaching experience. Participants did not differ demographically from families in the same school who had participated in the community's annual school readiness survey $(p$ all $>.05)$.

\section{Data Collection Procedure}

The study protocol was developed and piloted in consultation with local schools, the PFL programme team, and external experts, and received full ethical approval from the institution's ethics committee. Trained, blinded researchers conducted one-to-one mixed-method interviews (two concurrently in the same room). Assent was sought using an illustrated booklet, followed by: (1) School Liking and Avoidance Questionnaire, (2) semi-structured questions, (3) Pictorial Measure of School Stress and Wellbeing, and (4) Draw and Talk activity. Structured and unstructured measures aimed to elicit a wide range of children's perspectives. Interviews ( $\sim 45$ minutes) were audio recorded.

\section{Methods}

School liking and avoidance. The School Liking and Avoidance Questionnaire (SLAQ; Ladd, 1990) has 14 items, a 9-item school liking subscale (e.g. "Is school fun?") and a 5-item school avoidance subscale (e.g. "Do you ask your Mum or Dad to let you stay home from school?"). Children respond verbally using a three-point scale (yes, sometimes, no). Children's unstructured expansions to questions were analysed qualitatively.

What would Riley Rabbit need to know about school? Children were asked what an anthropomorphised character, Riley Rabbit, starting school for the first time, would need to know about school. Further questions focused on: advice, anticipated likes/dislikes, what Riley would find easy/difficult, peer relationships, and what children would change about school. Anthropomorphised characters are familiar and avoid differences in participants' identification with the character based on perceived likeness (Tatlow-Golden, Hennessy, Dean, \& Hollywood, 2013). This semi-structured measure sought to offer children the opportunity to describe what was most salient to them.

The Pictorial Measure of School Stress and Well-Being (PMSSW). As young children's verbal proficiency is still developing, visual prompts may be preferable (Mukherji \& Albon, 2010) and more valid. The PMSSW (Murray \& Harrison, 2005, 2014), developed in Australia, presents line drawings to assess children's views of potentially stressful school situations. Figures are depicted with blank faces, to allow participants to project feelings on to them. Children viewed nine adapted images reflecting typical Irish primary schools (Tatlow-Golden, O'Farrelly, Booth, O'Rourke, \& Doyle, 2016; Figure 1). For each, participants were asked: How does the child in the picture feel? Why do they feel that way? Would they tell the teacher how they are feeling? Why would they [not] tell the teacher? What might happen next? 


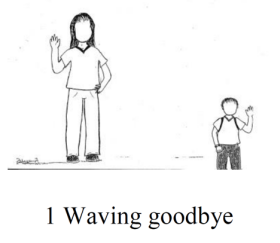

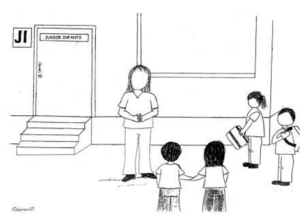

2 Lining up outside classroom

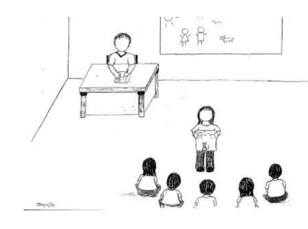

3 Speaking to class/telling news
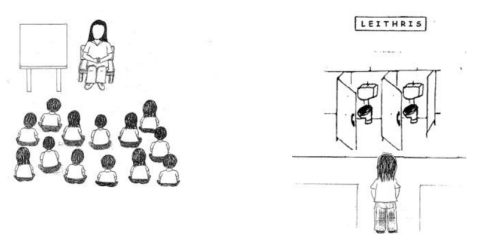

4 Listening to the teacher

5 Going to the toilet (Leithris)

Figure 1. PMSSW (Murray \& Harrison, 2014) adapted for the Irish primary school context

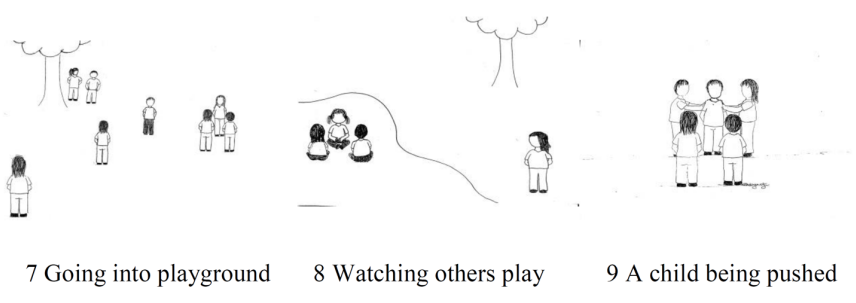

Draw and talk activity. For this open activity, children were invited to draw a 'special picture just about you in school' and tell the researcher about it. Drawing is a common and generally enjoyable activity and, in contrast to more structured measures, provides children with more control and time to shape their output (Einarsdottir, Dockett \&, Perry, 2009). As accompanying narratives inform the drawing itself (Einarsdottir et al., 2009), these were analysed together (Mitchell, Theron, Stuart, Smith, \& Campbell, 2011).

\section{Analytic Strategy}

Descriptive analysis examined the proportion of children with very negative views towards school on the SLAQ (average score $<2$ ) and the valence (positive, negative, ambivalent/other) of children's affective responses to the nine PMSSW scenarios.

The main qualitative data included responses to semi-structured questions; children's co-occurring and summative accounts of their drawings, and expansions to the SLAQ and PMSSW. Using principles of thematic analysis (Braun \& Clarke, 2006), data were coded inductively by the first author, aiming to record all aspects of children's experiences. Salient features of the transcript were coded systematically in a manner similar to line-by-line coding used in grounded theory. This strategy 
CHILDREN'S SCHOOL READINESS PRIORITIES O'Farrelly et al ECRQ 2019

forces the researcher to think about the data at a discrete level, attenuating the influence of the researcher's expectations (Charmaz, 2008). This helps to ensure that meaning is not overlooked in children's interviews, which are typically less dense than those of adults (Harden, Backett-Milburn, Hill, \& MacLean, 2010). Codes were categorised through a process of continuous refinement to "define and refine" the thematic framework (Braun \& Clarke, 2006, p.92). In an Excel database, every code was ascribed identifiers (participant number and measure) to identify how the data patterned across the sample and measure type, and support later auditing (Yardley, 2008).

The second and third authors reviewed codes, categories, and themes in "ongoing reflexive dialogue" (Braun \& Clarke, 2006, p.82) to ensure the results faithfully represented the data from multiple perspectives. Differences were resolved through discussion and minor revisions were made. Following Consensual Qualitative Research recommendations (Hill, Knox, Thompson, Williams, \& Hess, 2005), an independent auditor (the fourth author) recoded $66 \%$ of randomly selected original transcripts for the final framework, to mitigate any effects of group think.

The next stage of thematic analysis was guided by the question "what is salient to children for their early school experiences?" This was used to foreground those aspects of experience that children linked (positively or negatively) to well-being and give less weight to purely descriptive codes and sub-themes (e.g., neutral descriptions of the physical environment).

Next, children's priorities were mapped on to outcome measures for the $P F L$ trial in a two-stage process. Children's priorities were distilled from themes and subthemes by COF and BB to extract the features children described as salient to their early school experiences and adjustment to school. Priorities were then compared against the primary PFL outcome measures at the item, subscale/domain, and total scale level. This process was used to identify whether, or to what extent, readiness outcome measures assessed each priority. Children's priorities were thus categorised as 'measured', 'partially measured', or 'not measured'. This process was validated by MT-G and AB.

\section{Results}

\section{Inductive Findings}

Using the question "what is salient to children for their early school experiences?" as a lens, key concepts were elicited from the coded data, forming subthemes, which were grouped into meaningful clusters to form four overarching themes: (1) feeling able and enthusiastic for school; (2) navigating friendships and victimisation; (3) supportive environments with opportunities to play; (4) bridging school and family life. Table 2 shows these themes, subthemes, and indicative quotes. A table displaying the full data for each theme including measure identifiers is available in Supplementary File B. Pseudonyms are used for readability. 
CHILDREN'S SCHOOL READINESS PRIORITIES O'Farrelly et al ECRQ 2019

Feeling able and enthusiastic for school. Across measures, the children portrayed largely positive feelings towards school, a setting where they felt happy, excited, and had fun: "Happy because school is the funnest place"; "I wish I can go to school every day"; "Hip, hip, hooray school". Children often cited school liking as the source of happiness and well-being, especially across PMSSW scenarios: "Em, happy...because they're in school...because they like school". Enthusiasm extended to learning: "Happy...ehm 'cause they're at school and they're goin' to learn ev'rythin', loads of stuff" and was expressed for both traditional learning such as reading, writing, and counting: "He likes to read books"; "Oh, I love the counting", as well as more creative forms such as art: "I like when we do painting and make Play-Doh", and blocks: "I like blocks, they're my favourite. I can make [a] castle... in my classroom".

Nonetheless, a small number of children reported negative and/or ambivalent views: "Sad because he wants to stay at home"; "Maybe she will get bored going to school every day I guess". This reflected the SLAQ findings that $7 \%$ of CTSS children held very negative views of school. Children also showed differentiated affective responses to the PMSSW school scenarios, showing lower affect in the toileting, ambiguous peer, and bullying scenarios, compared with others (see supplementary File A).

It was important to children to feel able in school and they conveyed a robust sense of self-efficacy. This was evident when they said there were no aspects of school they struggled with: "Ehm...nothing, I don't find anything hard". Many expressed ease in their schooling: "I always do my homework... I do it on my own"; "Ehm, it's easy to write things on the board...by our own", with some children describing outstanding abilities: "I do [writing] in my classroom and I'm the first finished. I'm fast, I'm faster than a speedboat". Perhaps reflecting these high levels of self-belief, numerous participants spontaneously showcased their skills: "I know how to spell my sister's name, will I do it?"; "I know what colours they are... I can do that, can you?" Validation was important, including teachers' commendations: "The teacher might say...to them "good work" and that's why she might feel happy", and praise from peers: "He's tellin' everyone [some news] and they're goin' to go and say very good".

Nonetheless, children also conveyed challenges when attempting certain activities, particularly surrounding academic work: "Work [is hard] ...eh because I don't know what the words say. And that's hard"; “[It's hard] to trace numbers...I don't like playing with numbers...'cause ehm they're hard". Despite this, some children described specific strategies and persistence for overcoming difficulties, whether independently: "I don't know how to read...[You can] practice...em when you're not good and you have to learn then you have to practice", with the aid of the teacher: "He would find hard... when he ehm tries to write somethin' and he can't...but then he can ask teacher to 
CHILDREN'S SCHOOL READINESS PRIORITIES O'Farrelly et al ECRQ 2019

help him”, or peers: “I don’t really [score goals]...I just ask me friends can they a little bit of help me".

The importance of feeling competent also extended to physical independence and self-regulation. For instance, several expressed a desire for independence in toileting: "She might be happy because she...might be getting a bit grown up now...em, she's gone out to the toilet on her own". Some described challenges in gross motor skills, through their experiences of falling in the playground: "I always fall in yard [playground]... I don't like when I fall and cry"; "If she runs and falls.... It's really hard". Children also acknowledged competence in regulating behaviour and attention and following direction: "She feels happy because she's sitting on the ground and she's very listening"; "Happy... because she is doing what she is told". Many children were aware that these behaviours allowed them to be seen, by others and themselves, as 'good' in school: "I'm good...I'm good in the whole school...yeah the whole the gooder boy...look I have my ears open"; "Be good...sitting on me chair doing what teacher is telling us".

Navigating friendships and victimisation. Across interviews, well-being in school equated with the ability to initiate and maintain positive peer relationships. Having friends was often the reason children liked school: "Fun....'cause we have friends". As well as enjoyment, friendships afforded a sense of connection and belonging, as evoked in one child's drawing: "I'm going to do all my friends...here's all the friends lining up...now there's our school." Several children mentioned that every pupil could act as a potential friend or playmate: "Everyone in my classroom is my friend...I have fourteen friends to play with". 
CHILDREN'S SCHOOL READINESS PRIORITIES O'Farrelly et al ECRQ 2019

Table 2.

Themes, subthemes, and indicative quotes identified in inductive analysis

\begin{tabular}{|c|c|c|}
\hline Theme & Sub-theme & Illustrative data extract \\
\hline \multirow{4}{*}{$\begin{array}{l}\text { Feeling able and enthusiastic } \\
\text { for school }\end{array}$} & Positivity towards school & no I love school...He will like everything...I like everything as well. \\
\hline & An enthusiasm for learning & $\begin{array}{l}\text { happy...ehm 'cause they're at school and they're goin' to learn ev'rythin' loads of stuff...happy...'cause he's gettin' to } \\
\text { learn stuff }\end{array}$ \\
\hline & Feeling able & $\begin{array}{l}\text { I know what colours they are, blue, green, yellow, orange, red and brown... I just know the colours. Yellow, red, blue } \\
\text { and green and brown and red and yellow I can do that, can you? }\end{array}$ \\
\hline & $\begin{array}{l}\text { Identifying and overcoming challenges } \\
\text { An ability to self-regulate }\end{array}$ & $\begin{array}{l}\text { no... [Riley can't read, he can] practice...Em when you're not good and you have to learn then you have to practice } \\
\text { she feels happy because she's sitting on the ground and she's very listening and the teacher won't give out [get cross] to } \\
\text { her }\end{array}$ \\
\hline \multirow[t]{4}{*}{$\begin{array}{l}\text { Navigating friendships and } \\
\text { victimisation }\end{array}$} & $\begin{array}{l}\text { Access to friends for enjoyment and } \\
\text { support }\end{array}$ & happy...because she meets new friends at school I guess...happy if she finds a friend \\
\hline & $\begin{array}{l}\text { The art of making and maintaining } \\
\text { friends }\end{array}$ & because she is shy to ask them can she play... Say, 'please can I play?'... They will let her play. \\
\hline & Feeling distressed and victimised & $\begin{array}{l}\text { sad...and he's crying for his mammy...because they push him ...they are mad at him...Pushing him and punching him } \\
\text { in the face...He goes outside and he's crying...Mad...Cos they're about to push him. Them are his friends...Evil....cos } \\
\text { they think he done him }\end{array}$ \\
\hline & Feeling isolated & $\begin{array}{l}\text { and I betcha they're all playing... [how does child feel]...lonely... because nobody's playing with her... sad because } \\
\text { nobody's playing and asking her... and people won't play with her }\end{array}$ \\
\hline \multirow[t]{5}{*}{$\begin{array}{l}\text { Supportive environments } \\
\text { with opportunities to play }\end{array}$} & Play is (fun)damental & $\begin{array}{l}\text { Hlike drawing, doing playing, playing with the animals, playing with the Play-Doh, playing with the sand, playing with } \\
\text { the doctor's surgery, that is all. }\end{array}$ \\
\hline & $\begin{array}{l}\text { Opportunities for play, imaginati } \\
\text { creativity }\end{array}$ & $\begin{array}{l}\text { we like we get to play two two times 'cause ehm we do play centres... ehm and there's pictures of what we're goin' to } \\
\text { go to...ehm sometimes I play with fishin'...yeah and sometimes I like...playin' with the boats...ehm there's buildin' }\end{array}$ \\
\hline & $\begin{array}{l}\text { The yard is a place for imagination and } \\
\text { freedom }\end{array}$ & $\begin{array}{l}\text { when you go out to yard you could draw on chalk...eh it's a wall thing and you ehm the chalk and you can draw } \\
\text { anything, it's big it's like this...it's bigger than my hands...I draw me eating ice-cream...he could play Spiderman out } \\
\text { in yard with his friends....and chasing.... and hide-n-go-seek...maybe coconut...coconut, coconut, coconut crack }\end{array}$ \\
\hline & Teacher can support and enc & $\begin{array}{l}\text { ehm I think he would find hard when he doesn't get when he doesn't ehm when he ehm tries to write somethin' and he } \\
\text { can't...but then he can ask teacher to help him...like if he can't draw a bunny rabbit like he asks teacher's help }\end{array}$ \\
\hline & The importance of rules and routine & $\begin{array}{l}\text { eh listen eh tell eh listen your rules. ...Eh be quiet, sit down, read a book...Eat your lunch, go out in yard. Em help your } \\
\text { teacher. }\end{array}$ \\
\hline $\begin{array}{l}\text { Bridging school and family } \\
\text { life }\end{array}$ & A bridge between there and here & $\begin{array}{l}\text { that's why I practice at home 'cause we always draw at home...I'm just gonna write my name here... I'm writing my } \\
\text { name...that's how you spell my name [spells name]...I learned that at home }\end{array}$ \\
\hline
\end{tabular}


CHILDREN'S SCHOOL READINESS PRIORITIES O'Farrelly et al ECRQ 2019

The whole family

A support network

Separation from family and home that's my sister, and that's my mammy, and that's me aunty...this is for, this picture is for me mammy; he's [cousin] over in the [big school] all the way over there... when I'm big... when I'm over in that school they [little cousins] might come here.... She's [little sister] only three...nowhere...no she stay at home... while I'm gone to school

Only when my mammy is sick, when we had the book sale and my mammy was sick and she was puking and I couldn't get a book. Then I had to go home, I had to go all the way over to my nanny and then I went all the way back to my house.

I was really sad because it was only a short day for us and I didn't want to go, I was crying...before school...Great but a bit great because I couldn't stop thinking about my mam... Just really sad... No [I didn't tell the teacher].... because I wouldn't like the people to laugh. 
Some children reflected on the need to make friends in adjusting to school. It was important to know that "you make loads of friends" when starting school, perhaps to offset the initial loneliness and anxiety some described. For example, one child noted others would not like the playground "because it's his first day in school... he's not friends with anyone", while another commented that a child entering the playground would feel "scared... because she doesn't know anybody". Interactions appeared to be particularly risky initially when peers were unfamiliar: "One girl was bold [naughty] to me...now she's nice"; "If you have a first day your friends will be mean to you and the next day they won't...because they don't know you".

A few children elaborated on the process of making friends. One said you could simply "pick some new friend, Sarah, she was a new friend I made", while others explained you have to "know their name" and "you have to tell each other our name". Being able to approach a group, particularly in the playground, was key: "She will have to know to say hi in the yard...maybe she will make some friends out in the yard I guess...yes I really think so". Yet children were also aware that such bids might not be successful, one child noted that "you ask them are you allowed to play with them. And they say yeah or no", while another was less optimistic "when people don't have a friend...they go "will you play with me?" and they say "no" 'cause they already have a friend".

Maintaining friendships could bring its own complications. One child described how behaviour could cause rejection: "Today [my friend] is not playing with me...because ...I was laughing". The sometimes unpredictable nature of friendship was framed as a potential source of distress and disappointment: "I just don't like Scott. Scott be's my friend and then not and then is and then not and then is".

Exclusion and isolation were also salient, particularly within responses to the PMSSW. Rejection could stem from friendships: "If [my best friends] don't play with me out in the yard I would get sad, if I don't find anybody"; "[Her friends] might not let her play...that's a bit rude doing that to your friends". Children often conveyed a general risk of exclusion and isolation which were linked to feelings of distress (e.g., sad, upset, and cross) and loneliness. For example, several interpreted ambiguous peer scenarios in the PMSSW as instances where other children "don't want to let [you] play". Additionally, a sense of isolation is captured in one child's explanation that a child would feel sad "because he has no one to play with, he has no one to speak to", while another spoke about being on the outside: "I bet you they're all playing... [she feels] lonely...because nobody's playing with her". Notably, children's descriptions of negative peer interactions often included connotations of helplessness: "She's just there and does not know what to do... she feels a bit sad because they're not looking at her, they're not even playing with her". 
Peer aggression and victimisation was another concern. As with exclusion, there was a sense that children often had few resources to manage aggression: "When some people don't like you, they hit you". Indeed, aggression was sometimes a feature of friendship: "I have a friend Mikey and he's four and I fell on the ground "cause he pushed me on the ground"; "One of the [friends] hit me... Jack, not Danny or Sam,...be hitting me...that's not fair on me". Likewise, the PMSSW's peer pushing/bullying scenario was sometimes interpreted as taking place in the context of friendships: "Cause they're his friends and they're not stopping”; "Sad, 'cause [they're] mad at him...pushing him and punching him in the face... he goes outside and he's crying... [he feels] mad...them are his friends". Unsurprisingly, peer aggression was cited as an aspect of school that new children would dislike: "[Riley wouldn't like others] pushing him and punching him in the face".

Supportive environments with opportunities to play. Children's accounts frequently centred on the importance of rich, varied play opportunities. 'Play' was the singular answer offered by most children when asked what they did in school: "I just play...I play in the home corner.... I play doctors." Play was what was 'good' 'great' and 'fun' about school. It was children's favourite thing, allowed them to feel 'happy', and it was important to know that you got to play in school: "I like...doing playing, playing with the animals, playing with the Play-Doh, playing with the sand, playing with the doctor's surgery, that is all".

Children valued opportunities to play in the classroom: "We have play centres... they're really like somewhere you can play... there's construction... and sand... and shop"; "When you do playtime you play a lot...because ehm yeah, you're in groups". However, they mostly referred to play in the yard [playground]. This seemed to provide space for movement and particular scope for imagination: "He could play Spiderman out in yard with his friends... and chasing....and hide-n-go-seek...maybe coconut...coconut, coconut, coconut crack"; "She can do hopscotch out in the yard...she can skip and she can go out to her friends"; "When you go out to yard you could draw on chalk...you can draw anything, it's big, it's like this...it's bigger than my hands". Many children portrayed a need for freedom outside: "I would change it for sunny...because I like playing in the yard...yes and because it rains and you have to go in"; "[change school] to always go out to the yard, yeah and use no tables", and described the negative effects of staying indoors: '[We get bored] 'cause ehm...'cause we don't get to play out in the yard". However, a few children associated the yard with negative feelings: "Sad...because they might not wanna go out the yard". This is perhaps unsurprising given that issues with falling, isolation, and peer exclusion were concentrated in the yard, rather than the classroom.

Children evidenced rich imaginations and creative thinking in descriptions of their play: "Horses...you hold on to people's hood"; "We take turns at doing cash registers... maybe we'll be do doing our shopping"; "You try to make something...eh, I was trying to make a princess". Creative 
CHILDREN'S SCHOOL READINESS PRIORITIES O'Farrelly et al ECRQ 2019

thinking for imaginative play seemed to come without difficulty to most, although one child remarked that peers could enhance the quality of play: "Happy [watching three peers play]...'cause it gives me new ideas as well, what I can play".

Children's accounts also indicated how the school environment constrained and promoted well-being. They recounted the regularity and predictability of the day's running order: "When it's 12 o'clock; they go in and they might be going up to the computer [room] and they put their coats on the back of their chairs". Knowing the rules was framed as helpful, guiding children in meeting behavioural expectations: "Be good, know the rule...stop what you're doing...look at the person whose talking...stay quiet...yeah there's three”. Children appeared to be motivated by rewards for compliance: "She feels happy because she's sitting on the ground and she's very listening and the teacher won't give out [be cross] to her"; "Practise at the end and do her work very good....and get a smiley face on it".

Teachers played a notable and supportive role, although mentioned relatively infrequently $(21 \%$ of children featured their teachers in their drawings). These relationships were generally described with affection: "Ahhm, happy... because she, I think she loves her teacher". Children enjoyed listening to and learning from the teacher and appreciated encouragement and assistance, with settling in: "His teacher he she might eh show him where everything is", bridging social interactions: "A bit shy to tell them... because [the teacher] will help her talk", play and work: "I need to get some help from the teacher every time. It is tricky", and feeling safe and secure: "Happy...cause of the teacher...em safe". The teacher's role in maintaining class behaviour was also valued, though children disliked strong reactions to misbehaviour: "He won't like eh roaring and shouting...teacher when they're being bold [naughty]"; "[my teacher] is very good but sometimes she is really sad and mad because sometimes people in our class be really naughty and really crazy". Relatedly, children described their desire for the teacher to manage playground conflict, but were less clear about whether and how teachers would intervene: 'Sad, 'cause he ehm they gettin' pushed and the teacher's out in the classroom havin' her lunch". More supervision and support was also sought for toileting contexts: “Em not safe...not happy...'cause...em a teacher has not gone with him".

Bridging school and family life. Family featured prominently in children's descriptions of their school experiences (e.g., children depicted family in $45 \%$ of drawings when asked to draw about school). A small number described how access to school was dependent on their parents. One child noted he went to school "if my mam wakes me up, and I be late all the time" while another commented that "when eh my mammy is tired they let me [stay home from school]", although others were clear that "your mammy won't let you stay off school". One child spoke about taking on responsibility for being ready for school: "I get up in the morning when my mammy and daddy sleep, get on my coat, get my school bag, and they wake up and see me getting them things...yeah even I 
CHILDREN'S SCHOOL READINESS PRIORITIES O'Farrelly et al ECRQ 2019

wash my face". A few children also spoke about learning at home: "My mam helps me if I don't know the words".

Particularly salient were moments when children's school and family lives intersected. Some described these positively: "Happy...because I go to school...because I say goodbye to my mam". However, several described emotional consequences of missing family: "Sad...because he wants to go home and kiss his mam"; "I miss my Dad, I miss my sister, I miss my Mammy, I miss my brother...'cause I never see them in school'. In some instances these feelings were linked to school avoidance "he can ring his ma and tell them he wants to go home", feeling wary in social interactions "a bit sad and shy... because she might miss her mammy", or proximity seeking: "Sad... and he's crying for his mammy... because they push him". There was an impression that some had limited resources or were not supported to regulate this distress: "Just really sad... to say goodbye ... No [I wouldn't tell the teacher]... because I wouldn't like the people to laugh". As one child advised, it was important to know that "your mammy can't stay with you" when you start school.

On the other hand, family (siblings and cousins) provided children with a social safety net, particularly in the playground: "My big brother Max, sometimes I always play with him...well, all the time I do it."; although this support was not always guaranteed: "I can play with my sister, but now she doesn't even want to play with me anymore". Children also referred to ties with their wider family and community who supported their school attendance including grandparents, aunts, uncles, and neighbours: "They all take turns of collecting me".

\section{Comparison Between Children's Priorities and Primary Outcome Measures of School}

\section{Readiness}

Having identified children's salient early experiences, the thematic framework and its contents were then used to identify 25 key features of early school adjustment elicited from children's views and experiences. Finally, school readiness outcome measures were mapped on to these; Table 3 presents the 25 children's priorities and their correspondence with item-level content of the primary outcome measures used in the $P F L$ trial (Supplementary File B displays the links between these priorities and the inductive themes from which they were derived). This analysis found that while school readiness outcome measures capture many aspects of functioning that children identify as salient to their early school adjustment, others were captured partially or not at all.

Writing, reading and counting skills, considered salient by children to their early school adjustment, were extensively captured by parent and teacher report in the DP-3, ASQ, and S-EDI, and direct assessment with the British Ability Scales II (BAS-II). For drawing, the ASQ, DP-3, and BAS-II capture fine motor skills and ability to copy shapes. However, the imaginative drawing which children described enthusiastically was not captured. 
CHILDREN'S SCHOOL READINESS PRIORITIES O'Farrelly et al ECRQ 2019

Table 3.

Comparison between early school adjustment factors derived from children's school experience, and primary outcome measures

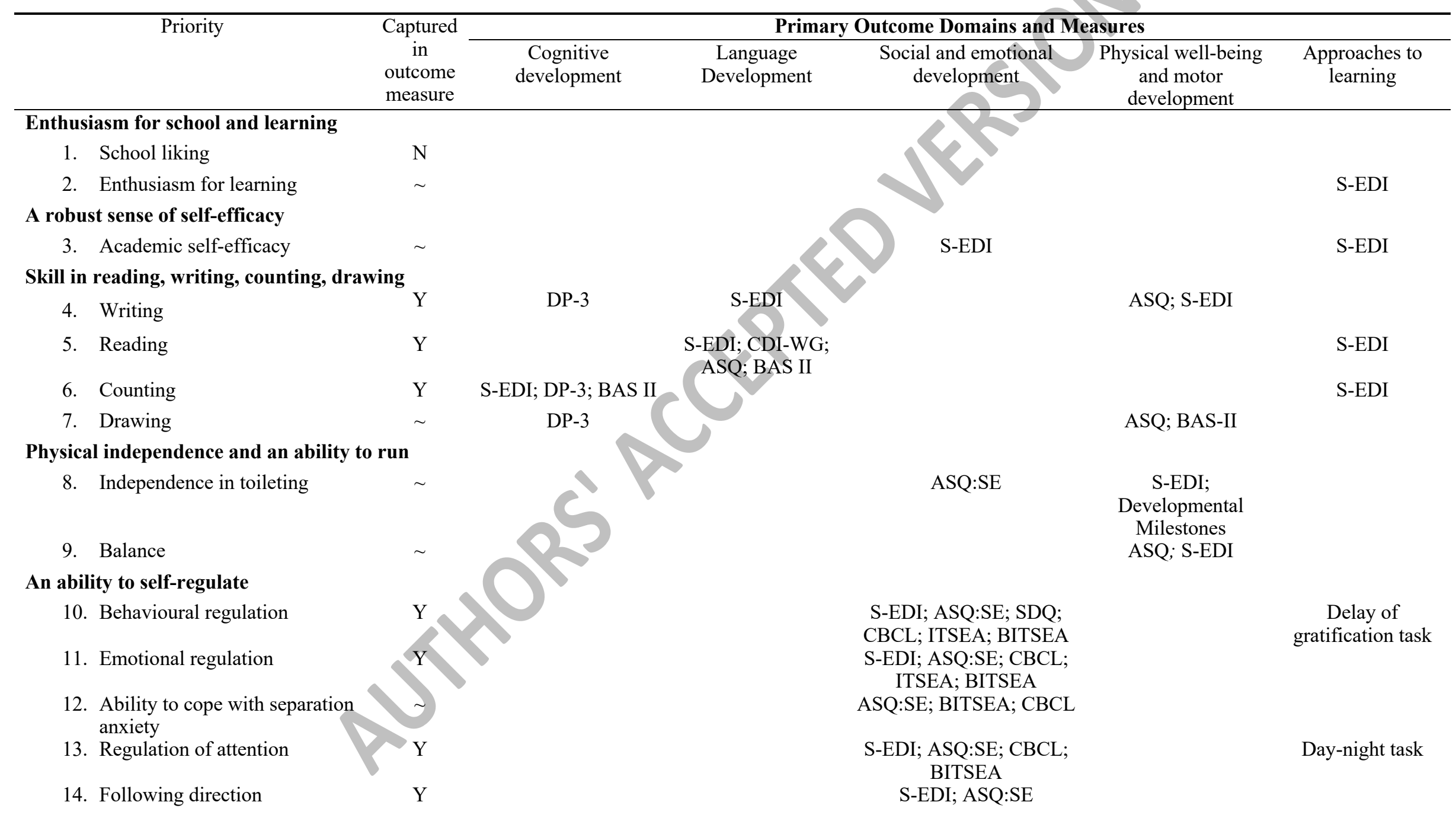


CHILDREN'S SCHOOL READINESS PRIORITIES O'Farrelly et al ECRQ 2019

\section{An ability to navigate peer interactions}
15. Social skills to establish and maintain friendships
16. Avoiding rejection
17. Conflict resolution

\section{An ability to think and play creatively}
18. An ability to think and play creatively

\section{Successful and supportive peer interactions}

19. Access to friends for enjoyment and support

20. Absence of social distress and victimization

\section{A supportive and playful school environment}
21. Regular access to play and
supportive outdoor space
22. Clear rules and routines
23. Supportive and encouraging
teacher relationships

\section{Bridging school and family life}
24. Strong family-school
involvement

25. Supportive social networks ${ }^{\mathrm{a}}$

\section{S-EDI; ASQ:SE; SDQ; \\ ITSEA; CBCL \\ ITSEA; SDQ}

S-EDI

S-EDI; ITSEA

S-EDI

Note. $\checkmark \mathrm{Y}=$ measured by outcome, $\sim=$ partially measured by outcome, $\mathrm{N}=$ not measured by outcome. Abbreviations: ASQ, Ages and Stages Questionnaire (Squires, Potter, \& Bricker, 1999); ASQ:SE, Ages and Stages Questionnaire: Social-Emotional (Squires, Bricker, \& Twombly, 2003); BAS II, British Ability Scales II (Elliot, Smith, \& McCulloch, 1997), BITSEA, Brief Infant Toddler Social and Emotional Assessment (Briggs-Gowan \& Carter, 2006); CBCL, Child Behaviour Checklist Preschool Form (Achenbach \& Rescorla, 2000); CDI-WG, MacArthur-Bates Communicative Development Inventories (Fenson, Pethick, Renda, Cox, Dale, \& Reznick, 2000); DP-3, Developmental Profile-3 (Alpern, 2007); ITSEA, Infant Toddler Social Emotional Assessment (Experiences with Other Young Children) (Carter \& Briggs-Gowan, 2006) SDQ, Strengths and Difficulties Questionnaire (Goodman, 1997); S-EDI, Short Early Development Instrument (Janus \& Stat, 2005). An appendix of PFL outcome measures and references are available in Supplementary File A. a $=$ Maternal social support was measured by the trial as a secondary outcome. 
CHILDREN'S SCHOOL READINESS PRIORITIES O'Farrelly et al ECRQ 2019

Balance was indexed by the ASQ gross motor scale (balance from a stationary position) and S-EDI (physical coordination), although neither assessed these skills in the playground setting. Independence in toileting was partially captured by parent interview items on age of toilet training, the ASQ:SE (ability to maintain dryness), and the S-EDI (independence in washroom habits); however, these did not capture confidence or capacity to ask to go to the toilet which were salient to children's accounts.

Children cited regulation of attention, behaviour, and emotion and these were quite well indexed through parent and teacher report on the S-EDI, ASQ:SE, Child Behavior Checklist (CBCL), ITSEA and Brief Infant Toddler Social and Emotional Assessment (BITSEA) and direct assessment using the day-night and the delay of gratification tasks. Following direction was well indexed by items on the S-EDI and ASQ:SE. Yet ability to cope with separation anxiety was only partially assessed by ASQ:SE, BITSEA, and CBCL general items on internalising behaviour. These items are likely to indicate children who may struggle with separation anxiety, yet may not fully correspond with children's ability to maintain a sense of security in school settings.

Social skills to establish and maintain friendships was broadly reflected in items assessing prosocial ability and social competence (S-EDI, ITSEA and ASQ:SE) and peer problems (SDQ and CBCL), which captured skills for maintaining friendships. However, none directly indexed the skills and confidence children described as necessary to initiate a social bid and join a peer group. Similarly, while the SDQ might indicate children already being rejected and the ITSEA measures those at risk of being rejected as perpetrators of bullying and ostracising behaviours, no measure identified the specific skills or resources that might enable children to avoid rejection. Lastly, the S-EDI includes items demonstrating children's capacity for empathy, prosociality and respect. These may be proxies for skills in conflict resolution, although none measured this directly.

No measure indexed children's school liking or children's affective responses to school, although some included items that asked about children's general mood (e.g., 'seems to be unhappy, sad, or depressed', S-EDI; 'does your child seem happy?' Ages and Stages Questionnaire: Social-Emotional; ASQ:SE). Enthusiasm for learning was partially measured by S-EDI items on children's interest in reading and numeracy and their eagerness to play with a new toy or book. Yet, these are somewhat narrow compared with children's accounts, which encompassed general eagerness to participate in classroom and outdoor activities. Furthermore, no measures captured children's task persistence, separate to general attention span. Similarly, academic self-efficacy was partially indexed by S-EDI items asking about children's ability to work independently and help others. However, none captured the degree 
CHILDREN'S SCHOOL READINESS PRIORITIES O'Farrelly et al ECRQ 2019

of pleasure children expressed about their sense of agency, mastery or identity and pride as an independent learner. Aspects of children's ability to think and play creatively were measured by the Ages and Stages Questionnaire (ASQ), Developmental Profile-3 (DP-3), and the Infant Toddler Social and Emotional Assessment (ITSEA) which include pretend and sociodramatic play items, while the S-EDI asks about eagerness to play. Although these capture conventional imaginative play such as 'dress-up', 'house', and 'dolls play' they do not fully reflect the rich and varied imaginative play children conveyed as salient.

\section{A Representation of Child Level Priorities of School Readiness}

Figure 2 depicts a multi-faceted model of factors children deemed salient to their early school experience and adjustment, including reciprocal individual, relational, and environmental factors. At its centre are children's motivation (including enthusiasm for school and learning), self-efficacy and perseverance. These underpin children's capacities and skills in five priority areas (self-regulation; thinking and playing creatively; reading, writing, counting, and drawing; navigating peer interactions; and physical independence) which influence, and in turn are shaped by, priorities for the teacher-child relationship, peer group, school environment, and relations between family, school and wider community contexts.

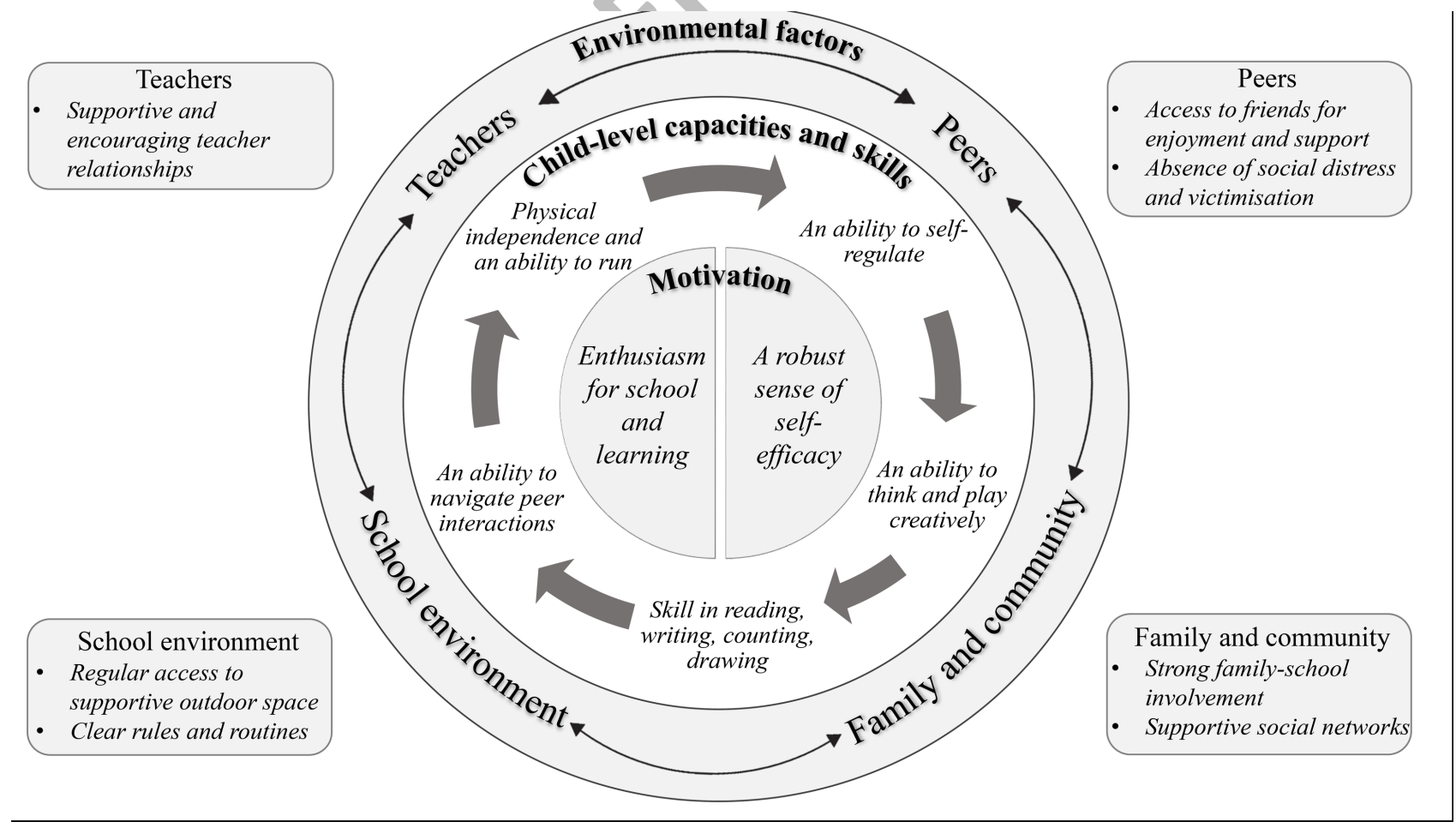

Figure 2. Priorities of school adjustment through the lens of the child: motivational, child-level, and environmental influences

\section{Discussion}


CHILDREN'S SCHOOL READINESS PRIORITIES O'Farrelly et al ECRQ 2019

This study aimed to illuminate young children's early school experience and adjustment in a community facing socioeconomic disadvantage. It further aimed to interrogate traditional benchmarks used to evaluate school readiness interventions, by comparing readiness outcome measures to children's early school adjustment priorities. We found that children portrayed early school adjustment as a multi-faceted construct: a motivational drive that underpins a broad range of capacities and skills, it is deeply social and influences and is shaped by its surrounding contexts. Children's responses strongly endorsed the view that school readiness is "more than a checklist of skills and contextually isolated knowledge and more than a set of behaviours that enable children to be considered as compliant in the classroom" (Dockett \& Perry, 2002, p.84). The findings also indicate that some features of early school adjustment that children experience as salient are not adequately captured by school readiness outcome measures.

In discussing these findings, we first consider the overarching early school experience themes derived from inductive analysis. We then address the 25 domains salient to children's early school adjustment that we extracted from their accounts, and consider how these can enrich school readiness measures.

\section{Children's Early School Experiences and Adjustment}

Feeling able and enthusiastic for school. A key finding is children's strong positive global feelings towards school that they linked to well-being. This corresponds with Ladd's findings that affective processes drive participation and academic progress (Ladd et al., 2000). Only $7 \%$ of children held highly negative global views of school, lower than $19 \%$ reported in a mixed SES sample (Ladd et al., 2000). This is notable as SES disparities in liking are evident in older children (Gutman \& Feinstein, 2008). Yet children also demonstrated differentiated emotional responses across school scenarios, responding more negatively to toileting and ambiguous peer scenarios. This pattern was similar to a mixed SES Australian sample (Harrison \& Murray, 2015), however affect was generally lower in the CTSS sample.

Children's enthusiasm for learning, including strong efficacy beliefs despite challenges, corresponds with evidence of young children's high motivation for learning irrespective of SES (Entwisle \& Hayduk, 1978; Howse, Lange, Farran \& Boyles, 2003; Stipek \& Ryan, 1997; Seefeldt et al., 1997; but see also Zill \& West, 2001). Perceptions of elevated ability may reflect a cognitive limitation of early self-concept (Thomaes, Brummelman, \& Sedikides, 2017), yet alongside agency, may provide a motivational drive for learning and encourage children to take on challenges via the pleasure they encounter in mastery (Denham \& Brown, 2010; Harter, 2008). Areas of concern regarding physical (i.e. balance and toileting) and selfregulation skills may be explained by socioeconomic inequalities (Blair \& Raver, 2012; 
CHILDREN'S SCHOOL READINESS PRIORITIES O'Farrelly et al ECRQ 2019

Robinson, 2011). These subjective concerns are rarely mentioned in the literature, yet may indicate barriers to physical participation and holding behaviours, elevating risk for poorer health and social outcomes (McPhillips \& Jordan-Black, 2007; Robinson, 2011; TatlowGolden, O'Farrelly, Booth, \& Doyle, 2016).

Navigating friendships and victimisation. Central to children's priorities was successful navigation of peer relationships; avoiding isolation, exclusion, and victimisation and wellbeing needs for friendships, support, and validation. Children sometimes reported that they felt helpless in the face of challenging peer interactions. In the absence of resources to manage these exchanges, young children's need to gain acceptance and avoid rejection may compromise their self-regulation and mental health (Arseneault et al., 2006; Stenseng, Belsky, Skalicka, \& Wichstrøm, 2015). As self-reports of aggression and bullying in preschool and kindergarten children are not unprecedented (Kirves \& Sajaniemi, 2012; Kochenderfer \& Ladd, 1996), supports for social and emotional learning in younger children may be warranted.

Supportive environments with opportunities to play. Priorities also extended to school, home, and community environments. Rather than reporting a loss of play, as is typical (Brooker, 2008; Seefeldt et al., 1997), children endorsed the value of play opportunities in classrooms and the playground, possibly due to the implementation of a local play-based curriculum (Preparing for Life, 2018). Further, children tended to couple references to play with happiness and seldom differentiated between play and learning. This corresponds with the idea that play cultivates children's learning and mastery drive (Hirsch-Pasek et al., 2009), and evidence that children show greater emotional well-being and problem-solving in activities perceived as play (Howard \& McInnes, 2012).

Outdoor play especially was seen as offering space to be imaginative, playful, sociable, and helped to sustain attention across the day. Recess/outdoor play has increasingly been linked to children's cognitive performance, creativity, and social adjustment (Blatchford, Pellegrini, \& Baines, 2016; Robson \& Rowe, 2012). Yet, descriptions of the playground's unstructured features also conveyed a sometimes risky and complicated space linked to injury, isolation, and victimisation (McNamara, Lodewyk, \& Franklin, 2018). References to teachers, while generally warm, were relatively infrequent and children conveyed a need for greater support and supervision in toileting and playground settings.

Bridging school and family life. Lastly, connections between school and family were important to children. In particular, some described separation anxiety as a source of distress and distraction. Relatedly, access to siblings/cousins was perceived as helping to avoid 
CHILDREN'S SCHOOL READINESS PRIORITIES O'Farrelly et al ECRQ 2019

isolation (Peters, 2003), perhaps due to a lower risk of rejection (Blatchford et al., 2016; Hartup, 1996).

\section{Comparison of Adjustment Priorities and School Readiness Measures}

To assess whether outcome measures capture children's adjustment priorities we crossreferenced children's accounts against a battery of school readiness assessments used in the PFL trial. Our findings suggest that children's priorities of core academic competencies such as numeracy and literacy, and some features of self-regulation, were well measured, but that other priorities regarding school adjustment were partially captured, and priorities for school environments were missing as they fall outside of typical batteries.

There were no measures of school liking and a partial view of children's self-efficacy. Measures tended to omit the affective and motivational attributes that influence how children inhabit academic skills. The outcome measures provided insight into children's prosocial behaviour and social competence, although more complex social interactions, including skills for friendship formation and avoiding victimisation, were not included. A further gap lies in measures capturing the breadth of children's imagination, creative thinking, and play. Our findings echo those of Tatlow-Golden and Guerin (2017) and Singh (2017) who found that salient aspects of children's self-concept (e.g., creativity and family) and quality of life are not accessed by traditional measures which may better reflect domains that adults believe matter to children's functioning, rather than children's own priorities.

\section{Conceptual Implications}

The dynamic, multifaceted and reciprocal model of school adjustment described by children closely corresponds with interactionist perspectives on readiness (Meisels, 1998). However our findings extend beyond Meisel's central axes of readiness, the child and educational environment, and give greater weight to children's motivation (i.e. liking and efficacy), social interactions with peers and play, and wider school, family, and community factors. These bioecological influences are not dissimilar to those considered by Rimm-Kaufman and Pianta (2000) in their framework on the transition to school and the characteristics of school success described by Ladd (2009) and Ramey and Ramey (1994). This is the first attempt however to conceptualise how these influences apply to school adjustment as derived from children's own priorities.

\section{Methodological Implications}

Children's experiences and priorities for their own adjustment to school provide insight into the face validity of readiness assessments and overlooked factors that may increase support for children's school success. Importantly, children endorse the significance of many of the 
CHILDREN'S SCHOOL READINESS PRIORITIES O'Farrelly et al ECRQ 2019

core academic skills that are central to current conceptions of school readiness and traditional batteries (e.g., reading, writing, numeracy, self-regulation). Further, some assessments, e.g., S-EDI (Janus et al., 2005), addressed a range of priorities or approximations. Possible augmentation of existing batteries could include measures to capture self-reported motivation; the SLAQ (Ladd, 1990), and the Berkeley Puppet Interview (Measelle, Ablow, Cowan, \& Cowan, 1998) offer starting points. Tools are also needed to tap into nuances of children's social skills, encompassing friendship formation and navigation of early victimisation, perhaps using pictorial prompts such as the PMSSW and the Challenging Situations Task (Denham et al., 2014). There is less clarity on how to measure play and creativity in young children (Resnick, 2017). Overall, it is important to consider how readiness features are manifest 'in situ' and the degree to which they are supported by the environment (Meisels, 1998). Measures that speak to areas such as motivation could also provide insight into children's potential, helping to rebalance concerns about the deficit focus of traditional measures (Brown, 2018).

\section{Practical Implications}

If the developmentally appropriate positive self-perceptions observed here replicate in similar samples, they could be used to optimise and sustain motivation early on (Harter, 2008). Transition planning (e.g., class visits; Schneider et al., 2014) and teacher practices (e.g., encouraging autonomy and choice, supportive feedback; Ryan \& Deci, 2016) offer viable routes. Doing so in low-SES contexts may help to attenuate the effects of disadvantage on later achievement (e.g., Schoon, 2008).

Children's accounts also support the potential value of early school-based supports for socioemotional experiences, as well as playful learning pedagogies. Social and emotional learning and guided play programmes, such as Tools of the Mind, are promising (Blair, McKinnon, \& Daneri, 2018; Durlak, Weissberg, Dymnicki, Taylor, \& Schellinger, 2011; Fisher, Hirsh-Pasek, Golinkoff, Singer, \& Berk, 2011). Strategies to promote strong parentschool involvement may also be protective in low-income communities, promoting greater readiness and academic and social functioning (Barbarin et al., 2010; Galindo \& Sheldon, 2012).

\section{Strengths and Limitations}

The participation and assent rates are in keeping with other studies, and although the sample was open to selection (e.g. based on parental educational experiences and children's language ability), participants' family characteristics reflected those who had participated in a wider school readiness study. The small gender imbalance may have influenced findings, although we did not observe a gender difference in SLAQ scores (not reported). Overall, given the 
CHILDREN'S SCHOOL READINESS PRIORITIES O'Farrelly et al ECRQ 2019

relatively small sample and qualitative analyses, we recommend the findings are best used to generalise to a theory (Yin, 2003) of child-centred school adjustment and its meaning for school readiness measures.

Although participant validation is often recommended for qualitative studies, time and participant burden constraints, and challenges of doing so with young children (Flewitt, 2005) precluded this. The results of this study may not reflect the experiences of children in other schools as a play-based curriculum was in operation. Indeed, children living in poverty are less likely to experience effective instruction and positive classroom climate (Pianta, La Paro, Payne, Cox, \& Bradley, 2002). The findings may also have been shaped by the two structured measures (SLAQ and PMSSW), for example in encouraging children to reflect on peer experiences. Lastly, this study assumes that children's early school adjustment, inferred from their salient early school experiences, can enrich our understanding of school readiness. However, these concepts, although related, are not completely aligned and alternative approaches assessing children's anticipation of school, with adult-led or closed questions, may have yielded different findings.

Nevertheless, this study's multi-method approach helped to maximise the experiences captured (Darbyshire, McDougall, \& Schiller, 2005), enhancing data validity (Dockett \& Perry, 2007). We employed a rigorous analytic approach, completing initial coding whilst blind to outcomes to avoid bias regarding specific priorities (Moore et al., 2015), and independently coded a substantial proportion of the dataset to mitigate any effects of group think (Hill et al., 2005). The study is one of few to elucidate the subjective early school experiences and adjustment of young children from disadvantaged communities. Additionally it is the first, to our knowledge, to interrogate school readiness outcome measures based on children's expressed priorities.

\section{Conclusion}

This study provides a model of school adjustment grounded in children's own priorities for their early school experience. Central to what matters to children is a sense of mastery, connectedness and inclusion, supportive spaces to be creative and playful, and strong ties between school and family lives. While academic aspects of school adjustment are very well captured by traditional measures of readiness, aspects of children's motivation, social skills and creativity, and features of the environment are missing.

There is no easy solution to the operational disarray of measures used to characterise school readiness. Adding new measures carries potentially prohibitive resource demands, adds to participant burden, and runs the risk of increasing confusion. Many existing measures also 
CHILDREN'S SCHOOL READINESS PRIORITIES O'Farrelly et al ECRQ 2019

have strong psychometric properties. Greater discussion of conceptual and operational approaches to school readiness and what it means for school adjustment is needed. Without this, assessments may unwittingly shape educational practice (e.g., Wesley, \& Buysse, 2003). Such discourse is timely as, more than ever, the contemporary world requires that children be creative and flexible thinkers (Fisher et al., 2011; Hirsch-Pasek et al., 2009; Resnick, 2017). While our results require replication and extension across more diverse samples, we provide a starting point in affording children's priorities a place in the policy and practice landscape that shapes their lives. 


\section{References}

Arseneault, L., Walsh, E., Trzesniewski, K., Newcombe, R., Caspi, A., \& Moffitt, T. E. (2006). Bullying victimization uniquely contributes to adjustment problems in young children: a nationally representative cohort study. Pediatrics, 118, 130-138. doi: 10.1542/peds.2005-2388

Azzi-Lessing, L. (2011). Home visitation programs: Critical issues and future directions. Early Childhood Research Quarterly, 26, 387-398. doi: 10.1016/j.ecresq.2011.03.005

Barbarin, O., Downer, J., Odom, E. \& Head-Reeves, D. (2010). Home-school differences in beliefs, support, and control during public pre-kindergarten and their link to children's kindergarten readiness. Early Childhood Research Quarterly, 25, 358-372. doi: 10.1016/j.ecresq.2010.02.003

Blair, C., McKinnon, R. D., \& Daneri, M. P. (2018). Effect of the tools of the mind kindergarten program on children's social and emotional development. Early Childhood Research Quarterly, 43, 52-61. doi: 10.1016/j.ecresq.2018.01.002

Blair, C., \& Raver, C. C. (2012). Child development in the context of adversity: Experiential canalization of brain and behavior. American Psychologist, 67, 309-318. doi: $10.1037 / \mathrm{a} 0027493$

Blatchford, P., Pellegrini, A. D., \& Baines, E. (2016). The child at school: $\quad$ Interactions with peers and teachers. London: Routledge

Boivin, M., \& Bierman, K. L. (2014). School readiness: Introduction to a multifaceted and developmental construct. In M. Boivin \& K. L. Bierman (Eds.), Promoting school readiness and early learning: Implications of developmental research for practice (pp. 3-14). New York: Guilford Press.

Braun, V. \& Clarke, V. (2006) Using thematic analysis in psychology. Qualitative Research in Psychology, Vol. 3, pp. 77-101.

Britto, P. R. (2012). School readiness: A conceptual framework. New York: United Nations Children's Fund.

Brooker, L. (2008). Supporting transitions in the early years. Maidenhead: Open University Press McGraw Hill.

Brown, C. P. (2018). School readiness. In L. Miller, C. Cameron, C. Dalli, \& N. Barbour (Eds.), The Sage Handbook of Early Childhood Policy, (pp. 287-302). London: Sage

Brown, D. A., \& Lamb, M. E. (2015). Can children be useful witnesses? It depends how they are questioned. Child Development Perspectives, 9, 250-255. doi:10.1111/cdep.12142

Census. (2006). Retrieved from http://www.cso.ie/en/census/census2006reports/.

Center on the Developing Child at Harvard University (2016). From best practices to breakthrough impacts. Retrieved from http://www.developingchild.harvard.edu

Charmaz, K. (2008). Grounded theory. In J. A. Smith (Ed.), Qualitative psychology: m practical guide to research methods (2nd ed.) (81-110). Thousand Oaks: Sage.

Crawford, M. J., Robotham, D., Thana, L., Patterson, S., Weaver, T., Barber, R., . . \& Rose, D. (2011). Selecting outcome measures in mental health: the views of service users. Journal of Mental Health, 20, 336-346. doi: 10.3109/09638237.2011.577114

Darbyshire, P., McDougall, C., \& Schiller, W. (2005). Multiple methods in qualitative research with children: more insight or just more. Qualitative Research, 5, 417-436.

Denham, S. A., Bassett, H. H., Way, E., Kalb, S., Warren-Khot, H., \& Zinsser, K. "How would you feel? What would you do?" Development and underpinnings of preschoolers' social information processing. Journal of Research in Childhood Education, 28, 182-202. doi: 10.1080/02568543.2014.883558

Denham, S. A. \& Brown, C. (2010). "Plays nice with others": Social-emotional learning and academic success. Early Education and Development, 21, 652-680. doi:10.1080/10409289.2010.497450

Dockett, S. \& Perry, B. (1999). Starting school: What do the children say? Early Child Development and Care, 159, 107-119. 10.1080/0300443991590109

Dockett, S. \& Perry, B. (2002). Who's ready for what? Young children starting school. Contemporary Issues in Early Childhood, 3, 67-89.

Dockett, S., \& B. Perry (2004). Starting school: Perspectives of Australian children, parents and educators. Journal of Early Childhood Research, 2, 171-189.

Dockett, S. \& Perry, B. (2007). Trusting children's accounts in research. Journal of Early Childhood Research, 5, 47-63.

Dockett, S., Perry, B., Kearney, E., Hampshire, A., Mason, J. \& Schmied, V. (2011). Facilitating children's transition to school from families with complex support needs. Albury: Research Institute for Professional Practice, Learning and Education, Charles Sturt University. 
Doyle, O., Harmon, C. P., Heckman, J. J., \& Tremblay, R. (2009). Investing in early human development: Timing and economic efficiency. Economics and Human Biology, 7, 1-6. doi: 10.1016/j.ehb.2009.01.002.

Doyle, O. (2013). Breaking the cycle of deprivation: An experimental evaluation of an early childhood intervention. Journal of Statistical and Social Inquiry Society of Ireland, 41, 92-111.

Duncan, G., Dowsett, C. J., Claessens, A., Magnuson, K., Huston, A. C., Klebanov, P., . . \& Japel, C. (2007). School readiness and later achievement. Developmental Psychology, 43, 1428-1446. doi: 10.1037/0012-1649.43.6.1428.supp

Duncan G., \& Magnuson, K. (2011). The nature and impact of early achievement skills, attention, and behaviour problems. In G. Duncan, \& R. J. Murnane (Eds.), Whither opportunity: Rising inequality, schools, and children's life chances (pp 47-69). New York: Russell Sage Foundation.

Durlak, J. A., Weissberg, R. P., Dymnicki, A. B., Taylor, R. D., \& Schellinger, K. B. (2011). The impact of enhancing students' social and emotional learning: A meta-analysis of school-based universal interventions. Child Development, 82, 405-432. doi: 10.1111/j.14678624.2010.01564.x

Einarsdottir, J. (2010). Children's experience of the first year of primary school. European Early Childhood Education Research Journal, 18, 163-180. doi: 10.1080/13502931003784370

Einarsdottir, J., Dockett, S. \& Perry, B. (2009). Making meaning: children's perspectives expressed through drawings. Early Child Development and Care, 179, 217-232. doi: 10.1080/03004430802666999

Elliott, C., Smith, P., \& McCulloch, K. (1997). British Ability Scales II. London: NFER-Nelson

Entwisle, D., R., \& Hayduk, L., A. (1978). Too great expectations: The academic outlook of young children. Baltimore: John Hopkins University Press

Fabian, H., \& Dunlop A-W. (2007). Outcomes of good practice in transition processes for children entering primary school. Working Paper 42. The Hague, The Netherlands: Bernard van Leer Foundation.

Filene, J. H., Kaminski, J. W., Valle, L. A., \& Cachat, P. (2013). Components associated with home visiting program outcomes: A meta-analysis. Pediatrics, 132, S100-S109. doi: 10.1542/peds.2013-1021H

Fisher, K. R., Hirsh-Pasek, K., Golinkoff, R. M., Singer, D., \& Berk, L. E. (2011). Playing around in school: Implications for learning and educational policy. In A. Pellegrini (Ed.), The Oxford handbook of the development of play (pp. 341-360). New York, NY: Oxford University Press.

Flewitt, R. (2005). Conducting research with young children: Some ethical considerations. Early Child Development and Care, 175, 553-565. doi: 10.1080/03004430500131338

Galindo, C., \& Sheldon, S. B. (2011). School and home connections and children's kindergarten achievement gains: The mediating role of family involvement. Early Childhood Research Quarterly, 27, 90-103. doi: 10.1016/j.ecresq.2011.05.004

Gutman, L. M., \& Feinstein, L. (2008). Children's well-being in primary school: Pupil and school effects. Report No 25: Centre for Research on the Wider Benefits of Learning.

Goodvin, R., Meyer, S., Thompson, R. A., \& Hayes, R. (2008). Self-understanding in early childhood: associations with child attachment security and maternal negative affect. Attachment and Human Development, 10, 433-450, doi: 10.1080/14616730802461466.

Harden, J., Backett-Milburn, K., Hill, M., \& MacLean, A. (2010). Oh, what a tangled web we weave: Experiences of doing 'multiple perspectives' research in families. International Journal of Social Research Methodology, 13, 441-452. doi: 10.1080/13645571003650979

Harrison, L. J., Clarke, L., \& Ungerer, J. A. (2007). Children's drawings provide a new perspective on teacher-child relationship quality and school adjustment. Early Childhood Research Quarterly, 22, 55-71. doi: 10.1016/j.ecresq.2006.10.003

Harrison, L. J., \& Murray, E. (2015). Stress, coping, and wellbeing in Kindergarten: Children's perspectives on personal, interpersonal and institutional challenges of school. International Journal of Early Childhood, 47, 79-103.

Harter, S. (2008). The developing self. In W. Damon \& R. M. Learner (Eds.), Child and adolescent development: An advanced course (pp. 216-262). New Jersey: Wiley

Hartup, W. W. (1996). The company they keep: Friendships and their developmental significance. Child Development, 67, 1-13. doi: 10.2307/1131681

Heckman, J. J. (2007). The economics, technology, and neuroscience of human capacity formation. PNAS, 104, 13250-13255. doi: 10.1073/pnas.0701362104

Henrich, C. C., Wheeler, C. M., \& Zigler, E. F. (2005). Motivation as a facet of school readiness in a Head Start sample. NHSA Dialog, 8, 72-87. doi:10.1207/s19309325nhsa0801_8

Hill, C., Knox, S., Thompson, B.J., Williams, E.N., \& Hess, S.A. (2005). Consensual qualitative research: An update. Journal of Counseling Psychology, 52, 196-205. doi: 10.1037/00220167.52.2.196 
Hirsh-Pasek, K., Golinkoff, R. M., Berk, L. E., \& Singer, D. G. (2009). A mandate for playful learning in preschool: Presenting the evidence. New York: Oxford University Press.

Horgan, G. (2007). The impact of poverty on young children's experience of school. York: Rowntree Foundation.

Howard, J., \& McInnes, K. (2013). The impact of children's perception of an activity as play rather than not play on emotional well-being. Child: Care, Health and Development, 39, 737-742. doi: 10.1111/j.1365-2214.2012.01405.x.

Howse, R. B., Lange, G., Farran, D. C., \& Boyles, C. D. (2003). Motivation and self-regulation as predictors of achievement in economically disadvantaged young children. The Journal of Experimental Education, 71, 151-174. doi: 10.1080/00220970309602061

Isaacs, J. B. (2012). Starting school at a disadvantage: The school readiness of poor children. The social genome project. Washington, DC: Center on Children and Families at Brookings.

Jackson, A. \& Cartmel, J. (2013). Young children's experience of starting school in an area of socioeconomic disadvantage. In S. E. Elliott-Johns, \& D. H. Jarvis (Eds.), Perspectives on transitions in schooling and instructional practice. Toronto: University of Toronto Press.

Janus, M., Duku, E.K., \& Stat, P. (2005). Development of the short early development instrument (S$E D I)$. Report for the World Bank.

Kagan, S. L. (2007). Readiness-multiple meanings and perspectives. In M. Woodhead \& P. Moss (Eds.), Early childhood and primary education: Transitions in the lives of young children, (pp. 12-14). Milton Keynes: The Open University.

Keating, I., Fabian, H., Jordan, P. Mavers, D., \& Roberts, J. (2000). 'Well, I've not done any work today. I don't know why I came to school'. Perceptions of play in the reception class. Educational Studies, 26, 437-454. doi: 10.1080/03055690020003638

Kirves, L., \& Sajaniemi, N. (2012). Bullying in early educational settings. Early Child Development and Care, 182, 383-400. doi: 10.1080/03004430.2011.646724

Kochenderfer, B. J., \& Ladd, G. W. (1996). Peer victimisation: Cause or consequence of school maladjustment? Child Development, 67, 1305-1317. doi: 10.1111/j.1467-8624.1996.tb01797.x

Ladd, G. W. (1990). Having friends, keeping friends, making friends, and being liked by peers in the classroom: Predictors of children's early school adjustment? Child Development, 61, 10811100. doi: 10.2307/1130877

Ladd, G. W., Buhs, E. S., \& Seid, M. (2000). Children's initial sentiments about kindergarten: Is school liking an antecedent of early classroom participation and achievement? Merrill-Palmer Quarterly, 46, 255-279.

Ladd, G.W. (2009). School transitions/school readiness: An outcome of early childhood development Perspective: Children's social and scholastic development - Findings from the Pathways Project. In R. E., Tremblay, M. Boivin, \& R. Peters (Eds.), Encyclopaedia on Early Childhood Development. Retrieved from: http://www.child-encyclopedia.com

Lansdown, G. (2005). Can you hear me? The rights of young children to participate in decisions affecting them. (Working paper No. 36). The Hague: Bernard van Leer Foundation.

Lansdown, G. (2010). The realisation of children's participation rights: Critical reflections. In B. Percy-Smith, \& N. Thomas (Eds.), A handbook of children and young people's participation: Perspectives from theory and practice (pp. 11-23). Abingdon, England: Routledge.

Luby, J. L., Belden, A., Sullivan, J., \& Spitznagel, E. (2007). Preschoolers' contribution to their diagnosis of depression and anxiety: Uses and limitations of young child self-report of symptoms. Child Psychiatry and Human Development, 38, 321-338. doi:10.1007/s10578-0070063-8.

MacNaughton, G., Hughes, P., \& Smith, K. (2007). Young children's rights and public policy: Practices and possibilities for citizenship in the early years. Children \& Society, 21, 458469. doi: 10.1111/j.1099-0860.2007.00096.x

Margetts, K. (2006, September). Teachers should explain what they mean": What new children need to know about starting school. Paper presented at the EECERA 16th Annual Conference, Reykjavik, Iceland.

Mashburn, A. J. (2104). The importance of quality prekindergarten programs for promoting school readiness skills. In S. H. Landry \& C. L. Cooper (Eds.), Wellbeing in children and families (pp. 271-296). Hoboken, NJ: Wiley Blackwell.

Measelle, J. R., Ablow, J. C., Cowan, P. A., \& Cowan, C. P. (1998). Assessing young children's views of their academic, social, and emotional lives: An evaluation of the self-perception scales of the Berkeley Puppet Interview. Child Development, 69, 1556-1576.

Meisels, S. J. (1999). Assessing readiness. In R. C. Pianta \& M. J. Cox (Eds.), The transition to kindergarten (pp. 39-63). Baltimore, MD: Paul H. Brookes Publishing.

McLoyd, V. C., Aikens, N., \& Burton, L. M. (2006). Childhood poverty, policy, and practice. In W. Damon, R. M. Lerner, K. A. Renninger, \& I. E. Sigel. (Eds.), Handbook of child psychology: Child Psychology in practice (pp. 700-775). Hoboken, NJ: John Wiley \& Sons. 
McNamara, L., Lodewyk, K., \& Franklin, N. (2018). Recess: A study of belongingness, affect, and victimization on the playground. Children \& Schools. doi: 10.1093/cs/cdy006

McPhillips, M., \& Jordan Black, J. A. (2007). The effect of social disadvantage on motor development in young children: a comparative study. Journal of Child Psychology and Psychiatry, 48, 1214-1222. doi: 10.1093/cs/cdy006

Mitchell, C., Theron, L., Stuart, J., Smith, A., \& Campbell, Z. (2011). Drawings as research method. In L. Theron, C. Mitchell, A. Smith, \& J. Stuart (Eds.), Picturing Research: Drawing as visual methodology, (pp. 19-36). Rotterdam: Sense Publishers.

Moore, G. F., Audrey, S., Barker, M., Bond, L., Bonell, C., Hardeman, W....Baird, J. (2015). Process evaluation of complex interventions: Medical Research Council guidance. British Medical Journal, 350, h1258. doi: 10.1136/bmj.h1258

Mukherji, P., \& Albon, D. (2010). Research methods in early childhood: An introductory guide. London: Sage Publications.

Murray, E. \& Harrison, L. J. (2005). Children's perspectives on their first year of school: Introducing a new pictorial measure of school stress. European Early Childhood Education Research Journal, Vol. 13, pp. 111-127. doi:10.1080/13502930585209591

Murray, E. \& Harrison, L. J. (2014). Pictorial measure of school stress and wellbeing- kindergarten: Instruction manual. New South Wales: Charles Sturt University.

National Education Goals Panel. (1991) The national education goals report: Building a nation of learners. Washington, D.C.: U.S. Government Publishing Office.

O'Kane, M. (2007). The transition to school in Ireland: What do the children say? In Vision in practice. Proceedings of a conference on making quality a reality in the lives of young children, 295301. Dublin: Centre for Early Childhood Education and Development

Onwuegbuzie, A. J., \& Collins, K. M. (2007). A typology of mixed methods sampling designs in social science research. The Qualitative Report, 12, 281-316.

Pawson R., \& Tilley N. (1997). Realistic evaluation. London: Sage

Peters, S. (2003). "I didn't expect that I would get tons of friends...more each day": Children's experiences of friendship during the transition to school. Early Years: An International Research Journal, 23, 45-53. doi: 10.1080/0957514032000045564

Pianta, R. C., La Paro, K. M., Payne, C., Cox, M. J., \& Bradley, R. (2002). The relation of kindergarten classroom environment to teacher, family, and school

characteristics and child outcomes. The Elementary School Journal, 102, 225-238.

Preparing for Life \& The Northside Partnership (2008). Preparing for Life programme manual. Dublin: Preparing for Life and the Northside Partnership.

Preparing for Life (2018). Schools programme: Play to Learn. Retrieved from https://www.preparingforlife.ie/schools-programme/\#1513374959088-eec757b3-3685

Ramey, S. L., \& Ramey, C. T. (1994). The transition to school: Why the first years matter for a lifetime. Phi Delta Kappan, 194-199.

Ramey, S. L., Lanzi, R. G., Phillips, M. M., \& Ramey, C. T. (1998). Perspectives of former Head Start children and their parents on school and the transition to school. The Elementary School Journal, 98, 311-327. doi: 10.1086/461898

Resnick, M. (2017). Lifelong kindergarten: Cultivating creativity through projects, passion, peers, and play. Cambridge, MA: The MIT Press

Rimm-Kaufman, S. E., \& Pianta, R. C. (2000). An ecological perspective on the transition to kindergarten: A theoretical framework to guide empirical research. Journal of Applied Developmental Psychology, 21, 491-511. doi: 10.1016/S0193-3973(00)00051-4

Rimm-Kaufman, S. E., \& Sandilos, L. (2017). School transition and school readiness: An outcome of

early childhood development. In R. E., Tremblay, M. a, \& R. Peters (Eds.), Encyclopaedia on Early Childhood Development. Retrieved from: http://www.child-encyclopedia.com/

Robinson, L. E. (2011). The relationship between perceived physical competence and fundamental motor skills in preschool children. Child: Care, Health and Development, 37, 589-596. doi: 10.1111/j.1365-2214.2010.01187.x.

Robson, S., \& Rowe, V. (2012). Observing young children's creative thinking: Engagement, involvement and persistence. International Journal of Early Years Education, 20, 349-364. doi: 10.1080/09669760.2012.743098

Ryan R. L., \& Deci, E. L. (2016). Facilitating and hindering determination, learning, and well-being in schools. In K. R. Wentzel, \& D. Miele (Eds.), Handbook of motivation at school (pp. 96-119). New York: Routledge.

Sabol, T. J. \& Pianta, R. (2017). The state of young children in the United States: School readiness. In E. Votruba-Drzal \& E. Dearing (Eds.), The Wiley handbook of early childhood development programs, practices, and policies (pp. 3-17). Oxford: John Wiley.

Sanders, M. R., Markie-Dadds, C., \& Turner, K. M. (2003). Theoretical, scientific and clinical foundations of the Triple P-Positive Parenting Program: A population approach to the 
promotion of parenting competence (Vol. 1). Queensland: Parenting and Family Support Centre, The University of Queensland.

Sama-Miller, E., Akers, L. Mraz-Esposito, A., Avellar, S., Paulsell, D., and Del Grosso, P. (2016). Home visiting evidence of effectiveness review. Washington, DC: Office of Planning, Research and Evaluation, Administration for Children and Families, U.S. Department of Health and Human Services.

Sameroff, A. (2009). The transactional model. In A. Sameroff (Ed.), The transactional model of development: How children and contexts shape each other (pp. 3-21). Washington, DC, US: American Psychological Association.Schickedanz, A., Dreyer, B. P., \& Halfon, N. (2015). Childhood poverty understanding and preventing the adverse impacts of a most-prevalent risk to pediatric health and well-being. Pediatric Clinics of North America, 62, 1111-1135. doi: 10.1016/j.pcl.2015.05.008.

Schneider, B. H., Manetti, M., Frattini, L., Rania, N., Santo, J. B., Coplan, R. J. \& Cwinn, E. (2014). Successful transition to elementary school and the implementation of facilitative practices specified in the Reggio-Emilia philosophy. School Psychology International, 35, 447-462.

Schoon, I. (2008). A transgenerational model of status attainment: The potential mediating role of school motivation and education. National Institute Economic Review, 205, 72-82.

Seefeldt, C., Galper, A. \& Denton, K. (1997). Head Start children's conceptions of and expectations for their future schooling. Early Childhood Research Quarterly, 12, 387-406. doi: 10.1016/S0885-2006(97)90018-1

Shonkoff, J. P. (2015). The neurobiology of early childhood development and the foundations of a sustainable society. In P. T. M. Marope \& Y. Kaga (Eds.), Investing against evidence. (pp. 5572). Paris: UNESCO Publishing.

Singh, I. (2017). What makes a life go well? Moral functioning and quality of life measurement in neurodevelopmental disorders - reflections on Jonsson et al. (2017). Journal of Child Psychology and Psychiatry, 58, 470-472. doi: 10.1111/jcpp.12716

Skinner, D., Bryant, D., Coffman, J., \& Campbell, F. (1998). Creating risk and promise: Children's and teacher's constructions in the cultural world of kindergarten. The Elementary School Journal, 98, 297-310.

Stenseng, F., Belsky, J., Skalicka, V., \& Wichstrøm, L. (2015). Social exclusion predicts impaired selfregulation: A 2-year longitudinal panel study including the transition from preschool to school. Journal of Personality, 83, 212-220. doi:10.1111/jopy.12096

Stipek, D. J., \& Ryan, R. H. (1997). Economically disadvantaged preschoolers: Ready to learn but further to go. Developmental Psychology, 33, 711-723.

Sweet, M. A., \& Appelbaum, M. I. (2004). Is home visiting an effective strategy? A meta-analytic review of home visiting programs for families with young children. Child Development, 75, 1435-1456. doi: 10.1111/j.1467-8624.2004.00750.x

Tatlow-Golden, M., \& Hennessy, E., Dean, M., \& Hollywood, L. (2013). 'Big, strong and healthy'. Young children's identification of food and drink that contribute to healthy growth. Appetite, 71, 163-170. doi: 10.1016/j.appet.2013.08.007

Tatlow-Golden, M., O'Farrelly, C., Booth, O’Rourke, C., \& Doyle, O. (2016). 'Look, I have my ears open': Resilience and early school experiences among children in an economically deprived suburban area in Ireland. School Psychology International, 37, 104-120. doi: $10.1177 / 0143034315613777$

Tatlow-Golden, M., \& Guerin S. (2017). Who I am: The meaning of early adolescents' most valued activities and relationships, and implications for self-concept research. The Journal of Early Adolescence, 37, 236-266. doi: 10.1177/0272431615599064

Tatlow-Golden, M., O’Farrelly, C. Booth, A., \& Doyle, O. (2017). "Bursting” to go and other experiences: Children's views on using the toilet in the first school year. The Journal of School Nursing, 33, 214-222. doi: 10.1177/1059840516646422

Thomaes, S., Brummelman, E., \& Sedikides, C. (2017). Why most children think well of themselves. Child Development, 88, 1873-1884. doi: 10.1111/cdev.12937.

United Nations (1989). Convention on the rights of the child. New York: United Nations.

United Nations Committee on the Rights of the Child. (2005). Implementing child rights in early childhood, general comment No. 7. Geneva: United Nations.

Valiente, C., Lemery-Chalfant, K. \& Castro, K. S. (2007). Children's effortful control and academic competence: Mediation through school liking. Merrill-Palmer Quarterly, 53, 1-25.

Wesley, P. W., \& Buysse, V (2003). Making meaning of school readiness in school and communities. Early Childhood Research Quarterly, 18, 351-375. doi: 10.1016/S0885-2006(03)00044-9.

Wong, M. (2015). Voices of children, parents and teachers: How children cope with stress during school transition. Early Child Development and Care, 185, 658-678. doi: 10.1080/03004430.2014.948872. 
CHILDREN'S SCHOOL READINESS PRIORITIES O'Farrelly et al ECRQ 2019

Yardley, L. (2008). Demonstrating validity in qualitative psychology. In J. A. Smith (Ed.), Qualitative psychology: A practical guide to research methods (235-251). ( $2^{\text {nd }}$ ed.). Thousand Oaks: Sage.

Yin, R. K. (2003). Case study research: Design and methods (3rd ed., Vol. 5). Thousand Oaks, CA: Sage.

Zill, N., \& West, J. (2001). Entering kindergarten: A portrait of American children when they begin school. Findings from the condition of education, 2000. Retrieved from:

https://nces.ed.gov/pubs2001/2001035.pdf 